KALAM, P-ISSN: 0853-9510 E-ISSN: 2540-7759

http://ejournal.radenintan.ac.id/index.php/KALAM

Volume 10, No. 2, Desember 2016, halaman 469 - 490

\title{
Dinamika Relasi Muhammadiyah dan NU Dalam Perspektif Teori Konflik Fungsional Lewis A. Coser
}

\author{
Khusniati Rofiah \\ IAIN Ponorogo, Jawa Timur \\ rofiahkhusniati@gmail.com
}

\begin{abstract}
Abstrak
Konflik atau perselisiban yang terjadi dalam masyarakat, seringkali dianggap sebagai suatu masalah yang negatif (disfungsional), yang dapat merusak perdamaian. Hal ini berbeda dengan Lewis A. Coser, yang justru mempunyai pandangan lain terbadap konflik. Baginya konflik justru memiliki "fungsionalitas" positif dalam masyarakat. Konflike yang terjadi antara Mubammadiyah dan NU tersebut sebagaimana teori konflik dari Coser tidak hanya bersifat disfungsional tetapi lebih banyak bersifat fungsional yaitu bersaing dalam hal kebaikan (Fastabiqul Khoirot). Dengan adanya konflik, pemahaman kesadaran pluralisme dan pikiran terbuka tertanam kuat pada setiap anggota Mubammadiyah dan NU. Penyelesaian konflik diantara keduanya dapat dilakukan melalui lembaga katup penyelamat (safety valve), misalnya kegiatan-kegiatan sosial dan intelektual yang melibatkan kedua belah pibak sebagaimana yang dilakukan oleb angkatan muda Muhammadiyah dan NU.
\end{abstract}

\begin{abstract}
Conflicts or disputes in society, often regarded as a problem that negative (dysfunctional), which can spoil the peace. This is in contrast to Lewis A. Coser, who actually has a different view of the conflict. For bim the conflict would have a "functionality" positive in the community. The conflict between Mubammadiyah and NU as conflict theory of Coser not only dysfunctional but more functional that is competitive in terms of goodness (Fastabiqul Khoirot). With the conflict, understanding consciousness pluralism and an open mind firmly planted on each member of
\end{abstract}


Mubammadiyah and NU. Conflict resolution between the two can be conducted through safety valve (safety valve), such as social activities and intellectual involving both parties, as was done by the younger generation of Muhammadiyah and NU.

Keywords: Relasi, Muhammadiyah, NU, Teori Konflik,
Fungsional.

\section{A. Pendahuluan}

Sosiologi adalah ilmu yang mempelajari tentang fenomena sosial yang terjadi dalam masyarakat. Fenomena sosial dalam masyarakat banyak ragamnya kadang kala fenomena sosial berkembang menjadi suatu masalah sosial akibat perbedaan cara pandang mengenai Fenomena tersebut. Dalam menyelesaikan masalah sosial dibutuhkan suatu teori untuk menyelesaikannya. Teori- teori tersebut lahir dari pengalaman-pengalaman yang terjadi dalam kehidupan sehari- hari. Karena setiap individu mengalami pengalaman yang berbeda maka teori yang muncul juga akan berbeda pula antara satu individu dengan individu lainnya. Disimpulkan bahwa tidak ada teori yang dapat menyeluruh membahas mengenai masalah sosial di masyarakat.

Salah satu teori sosiologi yang berpengaruh di Amerika pada tahun 1950-an adalah "teori struktural fungsional."1 Teori ini menekankan proses-proses sosial yang didasarkan pada konsensus nilai dan memandang masyarakat dari sisi solidaritas, integrasi, dan keseimbangan. Namun, para Sosiolog menganggap teori ini sebagai salah satu teori yang menutup mata terhadap konflik yang selalu melekat dalam setiap masyarakat. Dalam hal ini, teori fungsional struktural tidak melihat realitas bahwa masyarakat sesungguhnya dipenuhi oleh berbagai ketegangan dan selalu berpotensi untuk melakukan konflik. Teori fungsional cenderung melihat masyarakat berada dalam suatu posisi yang aman, damai, tentram, bersatu tanpa adanya konflik di antara mereka.

Di zaman modern ini, orang dengan berbagai aktivitas dan kepentingan silih berganti, kadang dapat membuat seorang individu

1 Zainuddin Maliki, Narasi Agung: Tiga Teori Sosial Hegemonik, (Surabaya : Lembaga Pengkajian Agama dan Masyarakat, 2003), h. 39. 
atau suatu kelompok mengalami disjungsi atau persinggungan dengan individu atau kelompok yang lain yang akan mengakibatkan konflik. Konflik yang berkepanjangan kadang dapat memperburuk tatanan sosial masyarakat. Namun, konflik juga berperan positif dalam memperkuat persatuan dan menghilangkan konflik intern dalam suatu kelompok. Konflik dimanapun bentuknya merupakan sesuatu yang wajar terjadi. Konflik senantiasa ada dalam setiap sistem sosial. Dapat dikatakan konflik merupakan merupakan suatu ciri dari sistem sosial. Tanpa konflik suatu hubungan tidak akan hidup. Sedangkan ketiadaan konflik dapat menandakan terjadinya penekanan masalah yang suatu saat nanti akan timbul suatu ledakan yang benar-benar kacau. Untuk itu dibutuhkan suatu teori yang dapat menekan bahkan memusnahkan konflik yang terjadi dalam kehidupan bermasyarakat.

Melihat gejala konflik yang kerap kali terjadi dalam struktur sosial masyarakat, para ahli sosiologi menyumbangkan berbagai gagasan atau ide-ide untuk memecahkan aneka konflik yang ada dalam masyarakat. Misalnya: G. Simmel dan Max Weber mengatakan bahwa konflik tidak dapat dihindarkan dalam realitas sosial masyarakat, tetapi konflik memainkan peranan positif dalam mempertahankan masyarakat, yaitu memupuk rasa pemersatuan. ${ }^{2}$

Konflik atau perselisihan yang terjadi dalam masyarakat, seringkali dianggap sebagai suatu masalah yang sangat kompleks, di mana kedua belah pihak yang sedang bertikai atau berselisih tidak mampu menciptakan suatu perdamaian, baik dalam relasi maupun dalam kehidupan sosial lainnya. Lewis A. Coser, seorang ahli sosioligi terkenal dari Amerika justru mempunyai pandangan lain terhadap konflik. Coser berpendapat bahwa konflik justru memiliki "fungsionalitas" positif dalam masyarakat.

Indonesia sebagai negara pluralitas yang penuh kemajemukan yang terdiri dari berbagai suku, agama, adat istiadat dan budaya, tidak terlepas dari berbagai konflik, baik konflik yang bernuansa suku, agama, ras dan antar golongan. Konflik yang terjadi banyak disebabkan oleh sikap eklusif yang tumbuh dari akar

2 Blasius Baene, Telaab Tentang Fungsionalitas Konflik Dalam Masyarakat Menurut Lewis A. Coser. Lihat http: http://sapereaudenias.blogspot.com/2008/ 08/telaah-tentang-fungsionalitas-konflik.html, diakses tanggal 20 Mei 2011 
primodialisme sempit kesukuan, agama dan golongan. ${ }^{3}$ Peristiwa konflik itu terjadi di beberapa daerah, baik dalam eskalasi kecil maupun besar dengan membawa korban baik jiwa maupun harta. ${ }^{4}$ Di antara konflik yang pernah terjadi di Indonesia adalah konflik yang terjadi antara Muhammadiyah dan NU.

Makalah yang sederhana ini berusaha membahas lebih jauh tentang teori konflik sosial yang dikemukakan oleh Lewis A. Coser. Selanjutnya makalah ini juga akan memaparkan pemakaian teori konflik sosial ini dalam menganalisis dinamika relasi NU dan Muhammadiyah yang terjadi di Indonesia.

\section{B. Biografi Lewis A. Coser}

Lewis A Coser dilahirkan dalam sebuah keluarga borjuis Yahudi pada tanggal 27 November 1913, di Berlin, Jerman. Lewis Coser memberontak melawan atas kehidupan kelas menengah yang diberikan kepadanya oleh orang tuanya, Martin (seorang bankir) dan Margarete (Fehlow) Coser. Pada masa remajanya ia sudah bergabung dengan gerakan sosialis dan meskipun bukan murid yang luar biasa dan tidak rajin sekolah tetapi ia tetap membaca voluminously sendiri. ${ }^{5}$

Ketika Hitler berkuasa di Jerman, Coser melarikan diri ke Paris, tempat ia bekerja serabutan untuk mempertahankan eksistensi dirinya. Ia menjadi aktif dalam gerakan sosialis, bergabung dengan beberapa kelompok-kelompok radikal, termasuk organisasi Trotskyis yang disebut "The Spark." Pada tahun 1936, ia akhirnya mampu mendapatkan pekerjaan yang lebih baik, menjadi

${ }^{3}$ Konflik sosial di Indonesia mulai muncul ketika rezim Orde Baru mulai melemah kekuasaannya dan Negara mulai kehilangan sebagian kontrolnya terhadap rakyat. Konflik ini terjadi di daerah-daerah yang sebelumnya terlihat "stabil", dimana konsep stabilitas menjadi bagian dari kredo rezim Oede Baru selain pertumbuhan ekonomi. Lihat Syafuan Rozi dkk, Kekerasan Komunal: Anatomi dan Resolusi Konflik di Indonesia, (Yogyakarta: Pustaka Pelajar, 2006), h. 1.

4 Balitbang Agama dan Diklat Keagamaan, Konflik Sosial Bernuansa Agama di Indonesia, (Jakarta : Depaq RI, 2003), h. 1-2. Dari tahun 1996 tercatat terjadi beberapa konflik sosial di Indonesia, diantaranya ; di Situbondo pada tanggal 10 Oktober 1996, di Tasikmalaya pada tanggal 24 Desember 1996, di Karawang pada tahun 1997, dan lain sebagainya.

5 http:/ /yoyoksiemo.blogspot.com/2007/07/lewis-coser-1913.html 
seorang ahli statistik untuk perusahaan broker Amerika. Dia juga terdaftar di Sorbonne sebagai mahasiswa sastra komparatif tetapi kemudian mengubah fokus untuk sosiologi.

Pada tahun 1942 ia menikah Rose Laub; mereka punya dua anak, Ellen dan Steven. Pada tahun 1948, setelah periode singkat sebagai mahasiswa pascasarjana di Columbia University, Coser menerima posisi sebagai tenaga pengajar ilmu sosial di Universitas Chicago. Pada tahun yang sama, ia menjadi warga negara AS naturalisasi. Pada tahun 1950, ia kembali ke Universitas Columbia sekali lagi untuk melanjutkan studinya, menerima gelar doktor pada tahun 1954. Ia diminta oleh Brandeis University di Waltham, Massachusetts pada tahun 1951. Pertama sebagai seorang dosen dan kemudian sebagai profesor sosiologi. Dia tetap di Brandeis, yang dianggap sebagai surga bagi kaum liberal, sampai 1968. Buku Coser tentang Fungsi Konflik Sosial adalah hasil dari disertasi doktoralnya. Karya-karya lainnya antara lain adalah; Partai Komunis Amerika: A Critical History (1957), Men of Ideas (1965), Continues in the Study of Sosial Conflict (1967), Master of Sosiological Thought (1971) dan beberapa buku lainnya disamping sebagai editor maupun distributor publikasi. Coser meninggal pada tanggal 8 Juli 2003, di Cambridge, Massachusetts dalam usia 89 tahun.

\section{Latar Belakang Munculnya Teori Fungsional Sosial Konflik}

Latar belakang munculnya pemikiran Coser tentang fungsi konflik sosial dapat dijelaskan dengan melihat kondisi inlektual, sosial dan politik pada saat itu. Kondisi intelektual adalah respon Coser atas dominasi pemikiran teori struktural fungsional dari Talcot Parsons dan Robert K. Merton yang merupakan orientasi teoritis dominan dalam sosiologi Amerika pada pertengahan tahun 1950.6

Teori struktural fungsional sangat menekankan prosesproses sosial yang didasarkan pada nilai atau konsensus normatif, keteraturan dan keselarasan. Teori ini juga memandang masyarakat berada dalam posisi yang aman, damai tentram, bersatu tanpa ada

${ }^{6}$ Lewis A. Coser, The Fungtions of Sosial Conflict, (New York USA: The Free Press, 1956), h. 11-21. 
konflik diantara mereka. Proses konflik dipandang dan diperlakukan sebagai sesuatu yang mengacaukan atau disfungsional terhadap keseimbangan sistem secara keseluruhan. Coser menolak terhadap pendapat mayoritas sosiolog AS yang berprasangka buruk terhadap konsep dan fungsi konflik sosial. Dalam pandangan Coser konflik tidak serta-merta merusakkan, berkonotasi disfungsional, disintegrasi ataupun patologis untuk sistem dimana konflik itu terjadi melainkan bahwa konflik itu dapat mempunyai konsekuensikonsekuensi positif untuk menguntungkan sistem itu. ${ }^{7}$

Adapun kondisi sosial politik pada saat Coser memunculkan teori fungsi konflik sosial ini adalah masih kuatnya pengaruh AntiSemitisme atau prasangka rasialisme, perang antar bangsa yang sering merangsang nasionalisme dan semangat patriotisme yang tinggi, pengurangan kebebasan dari orang Amerika-Jepang di Amerika Serikat dan berbagai konflik-konflik lainnya yang ikut manjadi kajian analisis Coser khususnya konflik antar kelompok dan solidaritas kelompok. Coser tidak ragu-ragu untuk menulis kritis tentang politik dan keadaan moral masyarakat. Sebagai reaksi terhadap intoleransi dari McCarthy pada 1950-an, ia dan temannya Irving Howe menciptakan anti kemapanan radikal lewat jurnal Dissent, yang diterbitkan secara berkala dalam publikasi jurnal. Dia menulis dalam otobiografinya kontribusi Sociological Lives (1988)

\section{Pemikiran Teori Fungsional Konflik Lewis A. Coser}

Teori tentang fungsional sosial konflik adalah salah satu teori konflik yang diperkenalkan pertama kali pada tahun 1956 melalui karya Lewis Coser yang berjudul The functions of Sosial Conflict yang diangkat dari desertasi doktoralnya. ${ }^{8}$ Teori konflik dari Coser ini diposisikan sebagai teori konflik modern yang bersifat naturalis. Coser lebih memusatkan perhatiannya pada fungsi-fungsi konflik yang membawa penyesuaian sosial yang lebih baik daripada menyoroti disfungsional konflik sebagaimana teori struktural fungsional sebelumnya.

7 Ibid, h. 16-17.

8 Buku ini diterbitkan tiga tahun sebelum diterbitkannya buku Dahrendorf edisi bahasa Inggris yakni, Class Conflict in Industrial Society, sosiolog Amerika yang sama-sama beraliran non Marxian. 
Pada umumnya istilah konflik sosial mengandung suatu rangkaian fenomena pertentangan dan pertikaian antar pribadi melalui dari konflik kelas sampai pada pertentangan dan peperangan internasional. ${ }^{9}$ Konflik dalam pandangan Coser adalah perjuangan atas nilai-nilai dan menuntut status yang langka, kekuasaan, dan sumber yang menetralisasikan tujuan-tujuan lawan untuk melukai atau mengeliminasi lawan-lawan mereka. ${ }^{10}$ Lewis A. Coser mengemukakan bahwa tidak ada teori konflik sosial yang mampu merangkum seluruh fenomena tersebut. Oleh karenanya ia tidak ingin mengkonstruksi teori umum, tetapi ia ingin karyanya sebagai suatu usaha untuk menjelaskan konsep konflik social bahwa konflik dapat mempunyai fungsi positif untuk suatu kelompok atau masyarakat daripada hanya merusakkan solidaritas, khususnya kalau isu-isu konflik itu diakui dan dihadapi secara terbuka daripada ditekan. ${ }^{11}$

Umumnya analisa Coser mengenai fungsi konflik sosial dapat dipandang sebagai suatu alternatif terhadap persepektifpersepektif teori konflik radikal yang diinspirasi pandangan Marxis. Menurut Coser, konflik $^{12}$ itu memiliki fungsi sosial. Coser

9 Menurut Webster, istilah konflik di dalam bahasa aslinya berarti suatu "perkelahian, peperangan atau perjuangan"-yaitu berupa konfrontasi fisik antara beberapa pihak. Tetapi arti kata itu kemudian berkembang dengan masuknya “ ketidaksepakatan yang tajam atau oposisi atas berbagai kepentingan, ide dan lain-lain." Dengan kata lain, istilah itu sekarang juga menyentuh aspek psikologis di balik konfrontasi fisik yang terjadi. Lihat Dean G. Pruitt, Jeffrey Z. Rubin, Teori Konflik Sosial, terj. Helly P. Soetjipto dan Sri Mulyantini, (Yogyakarta: Pustaka Pelajar, 2004), h. 9. Pengertian lain dari konflik dapat diartikan sebagai setiap pertentangan atau perbedaan pendapat antara paling tidak dua orang atau kelompok. Lihat Maswadi Rauf, Konsensus Politik, Sebuah Penjajagan Teoritis (Jakarta: Direktorat Jenderal Pendidikan Tinggi, Depdiknas, 2000), h. 2. Bandingkan dengan Ramlan Surbakti dalam Dasar-dasar Ilmu Politik (Surabaya: Airlangga University Press, 1984), h. 75.

10 Zeitlin M Irving, Memahami Kembali Sosiologi, Sunyoto (peny.), (Yogyakarta: Gadjah Mada University Press, 1998), h. 156.

11 Lewis A. Coser, The Functions Of Social Conflict (New York : The Free Press, 1956), h. 7.

12 Maswadi Rauf mengidentifikasi adanya tiga hal terkait dengan penyebab terjadinya konflik, yakni: pertama, posisi dan sumber-sumber kekuasaan, kedua, tingginya penghargaan terhadap posisi politik, serta ketiga, 
memadukan antara dua teori, yaitu teori fungsional struktural versus teori konflik. Oleh karena itu, teori konflik yang dikembangkan Coser disebut Fungsionalisme Konflik Sosial. Asumsinya dengan kombinasi maka kedua teori itu akan menjadi lebih kuat ketimbang masing-masing berdiri sendiri. ${ }^{13}$ Kedua teori ini mengandung kebenaran tetapi tidak mampu menjelaskan kenyataan sosial secara menyeluruh, karena nyatanya masyarakat itu sesekali terlibat konflik, tetapi sesekali juga terlibat kesepakatankesepakatan. ${ }^{14}$

Coser mendasarkan analisanya dalam "The Functions of Social Conflict"pada ide-ide Simmel bahwa konflik merupakan salah satu bentuk interaksi sosial yang dasar, dan bahwa proses konflik dihubungkan dengan bentuk-bentuk alternatif seperti kerjasama. Coser bukan tidak setuju dengan tekanan Parson pada tingkat analisa sistem sosial, juga tidak sepenuhnya mengikuti Simmel bahwa analisa sosial harus dipusatkan terutama pada bentuk-bentuk interaksi. Coser pada prinsipnya memiliki pandangan utama bahwa konflik tidak harus merusakkan atau bersifat disfungsional ${ }^{15}$

Coser menyatakan bahwa konflik sosial seringkali diabaikan oleh para ahli sosiologi, karena mereka cenderung menekankan pada sisi yang negatif yakni bagaimana telah meremehkan tatanan, stabilitas dan persatuan; pendek kata menggambarkan suatu keadaan yang terpecah belah. Coser ingin memperbaikinya dengan cara menekankan pada sisi konflik yang positif yakni bagaimana konflik itu dapat memberi sumbangan pada ketahanan dan adaptasi dari kelompok, interaksi dan sistem sosial.

Tidak dapat dipungkiri bahwa konflik adalah merupakan suatu gejala yang tidak dapat dihindari dalam kehidupan manusia. Namun, konflik yang terjadi dalam masyarakat bukanlah suatu persoalan yang tidak dapat diselesaikan. Coser mengatakan bahwa "tidak selamanya konflik berkonotasi negatif." Sebaliknya, konflik

kesempatan untuk memperoleh sumber daya yang langka. Lihat Maswadi Rouf, Konsensus Politik, h. 3.

13 George Ritzer dan Douglass J. Goodman, Teori Sosiologi Modern (Jakarta : Kencana, 2004), h. 159

14 Depag RI, Konflik Etno Religius Indonesia Kontemporer (Jakarta : Depag RI, 2003), h. 4.

15 Lewis A. Coser, The Fungtions, h. 72. 
memberikan fungsi positif dalam sosial masyarakat untuk untuk menyatukan kembali kelompok-kelompok yang sedang mengalami konflik sosial. Karena dengan adanya konflik, berarti masingmasing individu maupun kelompok di dalam komunitas itu berjuang untuk membangun dialog untuk mempertahankan integritas atau kesatuan sebagai anggota komunitas teristimewa dengan kelompok lain yang berasal dari budaya yang berbeda dengan dirinya. Selain itu, konflik dapat merangsang hidup setiap kelompok untuk merubah cara pandang yang pesimistis menjadi optimis untuk bersatu dengan kelompok-kelompok lain.

Coser memiliki pandangan bahwa konflik dalam masyarakat merupakan peristiwa normal yang dapat memperkuat struktur hubungan-hubungan sosial. Tidak adanya konflik dalam suatu masyarakat tidak dapat dianggap sebagai petunjuk kekuatan dan stabilitas hubungan sosial masyarakatnya. Perkembangan konflik dalam masyarakat bukanlah merupakan indikator utama dan tunggal untuk mengatakan bahwa stabilitas sosial dari masyarakat itu telah tercapai.

Tujuan Coser yang utama adalah memperlihatkan fungsi positif dari konflik dalam meningkatkan intregasi sosial. Konflik antara kelompok meningkatkan solidaritas internal dalam kelompok-kelompok yang berkonflik tersebut. Konflik di dalam kelompok mencegah antagonisme yang tidak dapat dihindari yang menandai semua hubungan sosial, dari menumpuknya sampai pada satu titik dimana hubungan itu sendiri menjadi terancam. Konflik juga meningkatkan perkembangan ikatan sosial anatara kelompok. Termasuk kelompok-kelompok itu sendiri. Konflik dapat juga merupakan suatu rangsangan utama untuk perubahan sosial.

Konflik sering memperkuat dan mempertegas batas kelompok dan meningkatkan penggalangan solidaritas internal kelompok. Konflik antarkelompok merupakan penghadapan antara in-group dan out-group. ${ }^{16}$ Ketika konflik terjadi, masing-masing

16 Pengertian in-group adalah orang-orang yang berada di dalam sebuah kelompok yang dikenal dengan "kelompok kita", orang kita atau keluarga sendiri". Sedangkan out group adalah semua orang yang berada di luar keanggotaan kelompoknya, atau dikenal dengan " kelompok mereka, atau orang lain". Tim Penyusun Kamus Pusat Pembinaan dan Pengembangan Bahasa, Kamus Besar Bahasa Indonesia (Jakarta : Balai Pustaka, 1990), h. 699 
anggota dalam suatu kelompok akan meningkatkan kesadaran sebagai sebuah kelompok (in-group) untuk berhadapan dengan kelompok lain (out-group). Kekuatan solidaritas internal dan integrasi kelompok dalam (in-group), akan meningkat karena permusuhan atau konflik yang terjadi dengan kelompok luar (out group) bersifat lebih besar. ${ }^{17}$ Konflik dapat menetapkan dan menjaga garis batas antara dua atau lebih kelompok. Konflik dengan kelompok lain dapat memperkuat kembali identitas kelompok dan melindunginya agar tidak lebur ke dalam dunia sosial lainnya. ${ }^{18}$ Ketika ada ancaman dari luar, maka kelompok tidak mungkin memberikan toleransi pada perselisihan internal.

Konflik-konflik dimana para pesertanya merasa bahwa mereka semata-mata merupakan wakil dari kolektivitas-kolektivitas atau kelompok - kelompok, berjuang bukan untuk dirinya tetapi hanya untuk cita-cita kelompok yang diwakilinya itu, sangat mungkin lebih radikal serta tak kenal ampun ketimbang mereka yang berjuang hanya untuk alasan-alasan pribadi. Penghapusan unsur-unsur personal cenderung mempertajam konflik karena tidak terdapatnya unsur - unsur pengubah dimana faktor - faktor pribadi biasanya akan dimasukkan.

Konflik antarkelompok ini kemudian dapat dikendalikan ketika semua kelompok dihadapkan pada tugas bersama yang merupakan tujuan bersama yang lebih tinggi (superordinate goals), yang pencapaiannya tak mungkin tanpa partisipasi seluruh kelompok. Maka terjadilah tranformasi dari situasi konflik ke relasi antarkelompok yang harmonis. Penyelesaian konflik antarkelompok berdasarkan teori konflik adalah berada pada tahap terakhir, yakni bagaimana mengubah konflik, pertikaian, atau perselisihan menjadi sebuah bentuk kerja sama. Konflik antarkelompok itu akan berubah menjadi kerja sama antarkelompok apabila kepada mereka diintroduksikan superordinate goals secara meyakinkan bahwa di atas hal-hal yang membuat mereka saling bermusuhan itu, ada hal yang jauh lebih penting untuk dihadapi bersama.

${ }^{17}$ Lewis A. Coser, The Functions, h. 33-38.

18 Poloma Margaret M, Sosiologi Kontemporer, Yasogama tim (terj.) (Jakarta : PT. RajaGarfindo Persada, 2000), h. 108. 
Konflik harus diakui keberadaannya, dikelola, dan diubah menjadi suatu kekuatan bagi perubahan yang positif. Coser menyatakan bahwa konflik adalah suatu komponen penting dalam setiap interaksi sosial. Oleh karena itu menurut Coser konflik tidak perlu dihindari, sebab Konflik dapat menyumbang banyak bagi kelestarian kehidupan sosial, bahkan mempererat hubungan antar anggota masyarakat. ${ }^{19}$

Dalam hal ini, menurut Lewis A. Coser, konflik dapat menimbulkan banyak cara untuk mempertahankan golongan atau kelompok dan menjadi lantaran mendapatkan perekat antar orang atau golongan. ${ }^{20}$ Lagi pula, menurut Robert C. North, konflik berfungsi sebagai pengikat antar kelompok atau golongan yang sebelumnya tidak menjalin hubungan. Karena itu, konflik suatu kelompok dengan kelompok lain menghasilkan mobilisasi energi para anggota kelompok yang bersangkutan sehingga kohesi setiap kelompok ditingkatkan. ${ }^{21}$ Bahkan, menurut Coser, konflik merupakan kualitas produktif daya hidup masyarakat yang akan menghasilkan perubahan-perubahan. ${ }^{22}$ Artinya, konflik dapat menghasilkan perubahan atau konsensus baru yang bermuara pada perbaikan. Agar konflik tidak merusak di luar control maka ia harus dikontrol lewat cara penyelesaian yang berangkat dari niat untuk take a little and give a little yang didasari i'tikat baik untuk berkompromi. ${ }^{23}$

Konflik juga membantu fungsi komunikasi. Sebelum konflik, kelompok-kelompok mungkin tidak percaya terhadap posisi musuh mereka, tetapi akibat konflik, posisi dan batas antar

${ }^{19}$ Lewis A. Coser dalam Makalah Mulyadi, Konflik Sosial ditinjau dari Segi Struktur dan Fungsi, Jurusan Antropologi, Fakultas Ilmu Budaya UGM, tanpa tahun, Yogyakarta.

20 Lewis A. Coser sebagaimana dikutip oleh Bungaran Antonius Simanjuntak, Konflik Status dan Kekuasaan Orang Batak Toba, h. 41.

Stanley Schachter, "Cohesion, Social", Encyclopedia of Social Sciences, Vol II, h. 542-5

21 Stanley Schachter, "Cohesion, Social", Encyclopedia of Social Sciences, Vol II, h. 542-5.

22 Ibid., h. 235

23 Loekman Soetrisno, Konflik Sosial Studi Kasus Indonesia (tk: Tajidu Press, 2003), h. 3. 
kelompok sering menjadi diperjelas. ${ }^{24}$ Karena itu individu bertambah mampu memutuskan untuk mengambil tindakan yang tepat dalam hubungannya dengan musuh mereka. Coser juga melihat konflik sebagai suatu stimulus untuk membentuk integrasi antarkelompok, artinya konflik sering merasa usaha untuk mengadakan persekutuan dengan kelompok-kelompok lain.

\section{E. Pembagian Konflik Menurut Coser}

Dalam membahas berbagai situasi konflik, Coser membedakan konflik yang realistik dan yang tidak realistik. ${ }^{25}$ Konflik yang realistis berasal dari kekecewaan terhadap tuntutantuntutan khusus yang terjadi dalam hubungan dan dari perkiraan kemungkinan keuntungan para partisipan dan yang ditujukan pada objek yang dianggap mengecewakan. Para karyawan yang mengadakan pemogokan melawan manajemen merupakan contoh dari konflik realistis, sejauh manajemen memang berkuasa dalam hal kenaikan gaji serta berbagai keuntungan buruh lainnya.

Sedangkan konflik yang tidak realistis adalah konflik yang bukan berasal dari tujuan-tujuan saingan yang antagonistis tetapi dari kebutuhan untuk meredakan ketegangan, paling tidak dari salah satu pihak. Seperti contoh dalam masyarakat yang buta huruf pembalasan dendam lewat ilmu gaib sering merupakan bentuk konflik non-realistis: sebagaimana halnya dengan pengkambinghitaman yang sering terjadi dalam masyarakat yang telah maju. Dalam hubungan antar kelompok, pengkambinghitaman digunakan untuk menggambarkan keadaan dimana seseorang tidak melepaskan prasangka (prejudice) mereka melawan kelompok yang benar-benar merupakan lawan dan dengan demikian menggunakan kelompok pengganti sebagai objek prasangka. ${ }^{26}$ Konflik non

\footnotetext{
${ }^{24}$ George Ritzer- Douglas J.Goodman, Teori Sosiologi, h. 159

25 Poloma, 1994: h. 111 - 114.

26Argyo Demartoto, Strukturalisme Konflik: Pemahaman Akan
} Konflik Pada Masyarakat Industri Menurut Lewis Coser Dan Ralf Dahrendorf, dalam Jurnal Dilema Sosiologi Issn : 0215 - 9635, Vol 24 No. 1 Tahun 2010. Prejudice (prasangka) merupakan faktor pelanggeng konflik, yakni sikap atau kepercayaan yang dimiliki seseorang untuk merendahkan orang lain, pernyataan negatif, atau pengungkapan perilaku permusuhan atau diskriminasi terhadap 
realistik mencakup ungkapan permusuhan sebagai tujuannya sendiri dan didorong keinginan yang tidak rasional serta cenderung bersifat ideologis, seperti konflik antaragama, antaretnis dan antarkepercayaan. Konflik yang non realistis ini cenderung lebih sulit untuk menemukan solusinya atau sulit mencapai konsensus dan perdamaian.

Menurut Coser terdapat suatu kemungkinan seseorang terlibat dalam konflik realistis tanpa sikap permusuhan atau agresi. Contoh: Dua pengacara yang selama masih menjadi mahasiswa berteman erat. Kemudian setelah lulus dan menjadi pengacara dihadapkan pada suatu masalah yang menuntut mereka untuk saling berhadapan di meja hijau. Masing-masing secara agresif dan teliti melindungi kepentingan kliennya, tetapi setelah meniggalkan persidangan mereka melupakan perbedaan dan pergi ke restoran untuk membicarakan masa lalu.

Akan tetapi apabila konflik berkembang dalam hubunganhubungan yang intim, maka pemisahan (antara konflik realistis dan non-realistis) akan lebih sulit untuk dipertahankan. Coser mengatakan bahwa, semakin dekat suatu hubungan semakin besar rasa kasih sayang yang sudah tertanam, sehingga semakin besar juga kecenderungan untuk menekan ketimbang mengungkapkan rasa permusuhan. Sedang pada hubungan-hubungan sekunder, seperti misalnya dengan rekan bisnis, rasa permusuhan dapat relatif bebas diungkapkan. Hal ini tidak selalu bisa terjadi dalam hubunganhubungan primer dimana keterlibatan total para partisipan membuat pengungkapan perasaan yang demikian merupakan bahaya bagi hubungan tersebut. Apabila konflik tersebut benarbenar melampaui batas sehingga menyebabkan ledakan yang membahayakan hubungan tersebut. ${ }^{27}$ Contoh: Seperti konflik antara suami dan istri, serta konflik sepasang kekasih.

Dalam satu situasi bisa terdapat elemen-elemen konflik realistis dan non-realistis. Konflik realistis khususnya dapat diikuti oleh sentimen-sentimen yang secara emosional mengalami distorsi oleh karena pengungkapan ketegangan tidak mungkin terjadi dalam

para anggota suatu kelompok masyarakat. Prejudice bisa bersifat kognitif, emosi atau tingkah laku. Lihat Depag RI, Konflik Etno Religius, h. 8.

${ }^{27}$ Lewis A. Coser, The Functions Of, h. 62. 
situasi konflik yang lain. Dengan demikian energi-energi agresif mungkin terakumulasi dalam proses-proses interaksi lain sebelum ketegangan dalam situasi konflik diredakan.

\section{F. Cara Penyelesain Konflik}

Coser melihat katup penyelamat berfungsi sebagai jalan ke luar yang meredakan permusuhan, yang tanpa itu hubunganhubungan di antara pihak-pihak yang bertentangan akan semakin menajam. Katup Penyelamat (savety-value) ialah salah satu mekanisme khusus yang dapat dipakai untuk mempertahankan kelompok dari kemungkinan konflik sosial atau suatu mekanisme yang dipakai untuk mempertahankan kelompok yang menghadapi konflik tanpa merusak hubungan kelompok itu sendiri. Misalnya, rasa kekecewaan, marah terhadap kelompok dapat disalurkan melalui lelucon, gambar atau lukisan dan lain sebagainya. Katup penyelamat ini bisa berupa sebuah institusi pengungkapan rasa tidak puas atas sebuah sistem atau struktur. Contoh: Badan Perwakilan Mahasiswa atau panitia kesejahteraan Dosen. Lembaga tersebut membuat kegerahan yang berasal dari situasi konflik tersalur tanpa menghancurkan sistem tersebut.

\section{G. Kritik Konflik Coser}

Sepeti banyak karya-karya yang disebut teori dalam sosiologi, karya Coser juga mengandung kelemahan - kelemahan metodologis. Secara naluriah konsep - konsepnya memang menyenangkan, tetapi tidak mungkin dijabarkan bagi pengujian empiris. ${ }^{28}$

Disisi lain, analisa konflik yang diajukan oleh Coser terlihat cenderung melihat konflik lebih pada proses yang berlangsung di tataran kelompok. Dalam hal ini kelompok dilihat sebagai penjumlahan individu, sehingga kemudian individu menjadi tenggelam dalam sebuah entitas dan tidak nampak sebagai aktor.

Suatu hal yang menarik adalah bahwa Lewis Coser menyimpan ambisi untuk menghimpun berbagai pendapat dari

28 http://socialmasterpice.blogspot.com/2011/03/teori-konflik-coserdahrendof.html, diakses tanggal 15 Mei 2011 
sejumlah ilmuwan, dan kemudian ia ingin menjadikan kesimpulankesimpulan. Namun sayangnya kesimpulan-kesimpulan yang ditarik kurang obyektif sehingga meski mengambil sikap positif dalam memandang konflik, namun konstruknya tentang konflik itu menjadi kurang realistik untuk diterapkan menghadapi realitas kontemporer.

\section{H. Dinamika Relasi NU dan Muhammadiyah di Indonesia.}

Kerukunan intern umat Islam di Indonesia, seperti juga pada umat-umat beragama lainnya, sering terganggu oleh riak-riak konflik intern, baik karena hal-hal yang bersifat doktriner maupun karena sebab-sebab lain di luar itu. Apalagi, umat Islam di Indonesia sebagian besar sudah lama berada dalam kotak-kotak organisasi yang membawa dan mengajarkan paham-paham keagamaan seperti Muhammadiyah, NU, Persis, Perti, al-Irsyad dan lain sebagainya. ${ }^{29}$

Sebagai dua organisasi keagamaan terbesar, keberadaan Muhammadiyah dan Nahdlatul Ulama dalam sejarah Indonesia modern memang amat menarik. Sepanjang perjalanan kedua organisasi Islam terbesar ini, senantiasa diwarnai kooperasi, kompetisi, sekaligus konfrontasi atau konflik. Apalagi selama ini, NU dikenal sebagai organisasi Islam tradisionalis dan knservatif yang berbasis masyarakat desa dengan tingkat ekonomi menengah ke bawah, sedangkan Muhammadiyah dikenal sebagai organisasi Islam yang modernis-substansialis yang berbasis masyarakat perkotaan dengan tingkat ekonomi menengah ke atas. ${ }^{30}$

Tak dapat dipungkiri, hubungan Muhammadiyah dan NU pernah diwarnai dengan konflik yang dipicu oleh perbedaan cara pandang keagamaan, meskipun sebenarnya tidak begitu prinsipil dan berada pada wilayah yang mudah diperdebatkan (khilafiyah) seperti penggunaan qunut dalam salat shubuh, jumlah rekaat shalat tarawih, ritus yang berkaitan dengan kematian, dan penentuan idul

29 Sjamsudduha, Konflik \& Rekonsiliasi NU Mubammadiyah, (Surabaya : PT. Bina Ilmu, 1999), h. 11.

30 Muttoharun Jinan, Arus Balik Aktivitas NU dan Muhammadiyah, dalam"Muhammadiyah-NU Mendayung Ukhuwah di Tengah Perbedaan", (Malang: UMM Press, 2004), h. 140. 
fitri. Karena tidak begitu prinsipil, seharusnya konflik bisa dinetralisir. Tapi yang terjadi malah konflik berkembang dalam radius yang luas dan melibatkan banyak segmen masyarakat. ${ }^{31}$

Disamping terjadi pada wilayah keagamaan, konflik antara Muhammadiyah-NU acapkali terjadi dalam wilayah politik. Ada dua jenis wilayah politik yang potensial memunculkan konflik. Pertama di parpol, sedangkan yang kedua di pemerintahan, yaitu di Departemen Agama. Dalam wilayah pertama, sebenarnya antara Muhammadiyah dan NU pernah memperlihatkan ikatan ukhuwah yang menggembirakan ketika bersatu dalam Masyumi. Namun ukhuwah dalam politik tidak dapat berlangsung lama karena NU keluar dari Masyumi yang konon disebabkan oleh kekecewaan NU terhadap dominasi kubu modernisme yang disokong Muhammadiyah.

Dialektika Muhammadiyah dan NU dalam sejarah politik Islam di Indonesia, dapat dirunut, paling tidak, sejak lahir tahun 1930-an, melalui MIAI (Majelis Islam A'la Indonesia), sebuah federasi untuk membina kerja sama berbagai organisasi Islam. Kompetisi dan kontestasi kedua tradisi Islam ini, sepanjang Orde Lama (Orla) dan Orde Baru (Orba), tampak dari rivalitas keduanya dalam Masyumi sepanjang 1945-1952 dan di PPP sepanjang tahun 1973-1984, respons terhadap Demokrasi Terpimpin dan Nasakom, serta respons terhadap rezim Orba. ${ }^{32}$ Dan pada akhirnya di masa

31 Syamsul Arifin, Menggagas Ukhuwah NU dan Muhammadiyah dalam "Muhammadiyah-NU Mendayung Ukhuwah di Tengah Perbedaan", (Malang : UMM Press, 2004), h. 12-13. Jika menelusuri sejarah umat Islam sampai kepada masa formatif, konflik yang terjadi antar NU dan Muhammadiyah, bisa dipandang sebagai kelanjutan dari konflik yang dialami umat Islam pada sejarah sebelumnya. Dalam masa-masa yang paling dini, umat Islam sudah sudah terlibat konflik yang besar sehingga dikenal dengan al-fitnah al-kubra (fitnah besar). Ada empat fitnah besar yang menjadi aib sejarah umat Islam. Pertama, pembunuhan Usman. Kedua, peperangan antara Ali dan Muawiyah, dan antara Ali dengan Aisyah. Ketiga, pengejaran habis-habisan keturunan Umayah dengan keturunan Abbasiyah dan keempat, perang antara dua bersaudara putra Harun alRasyid antara Amien dan Makmun. Konflik-konflik yang terjadi itu, mengakibatkan Islam dicitrakan sebagai agama yang penuh konflik.

32 Pramono U Tanthowi, Muhammadiyah dan NU dalam Kompetisi Makna "Civil Society",Kompas, Jumat, 6 Juli 2001 http://muhammadiyahstudies. 
reformasi ini lahirlah $\mathrm{PKB}$ dan PAN yang ternyata membawa akibat terjadinya konflik politik di kalangan umat Islam terutama antara Muhammadiyah dan NU yang disebabkan adanya persebrangan antara elit politik dari kedua partai.

Konflik politik antara Abdurrahman Wahid dan Amien Rais disadari atau tidak mengancam keharmonisan hubungan NUMuhammadiyah. Siapapun boleh mengatakan bahwa aktivitas politik kedua tokoh ini tidak ada kaitannya dengan NU dan Muhammadiyah. Sehingga pertentangan antara Gus Dur dan Amien Rais tidak berarti pertentangan antara NU dan Muhammadiyah. Hanya saja kita harus melihat bahwa paternalisme masyarakat Indonesia masih sangat kuat. Masyarakat kita masih sangat "tergantung" kepada pimpinannya. Secara psikologis umat tidak akan dapat begitu saja mengabaikan keduanya sebagai mantan pucuk pimpinan NU dan Muhammadiyah. Kharisma keduanya di mata pengikutnya menyebabkan keduanya masih dianggap sebagai pemimpin informal bagi kelompoknya.

Terjadilah kemudian tragedi-tragedi semisal penyilangan rumah-rumah warga Muhammadiyah di Banyuwangi dan beberapa tempat di Jawa Timur, perusakan fasilitas dan amal usaha Muhammadiyah, dan tindakan-tindakan destruktif lain yang mengancam hubungan dua ormas bersaudara ini. Penyebabnya jelas, lantaran massa grass root menurunkan konflik elit ke dataran yang massif yang lebih rendah. Secara psikologis, konflik politik antara Abdurrahman Wahid dan Amien Rais dianggap sebagai konflik antara NU dan Muhammadiyah.

Sementara itu, dalam wilayah pemerintahan telah menjadi rahasia publik bahwa antara Muhammadiyah dan NU terlibat persaingan merebut dominasi jabatan elite di lingkungan Departemen Agama. Pada periode orde baru, NU dapat mempertahankan dominasinya di Depag. Tetapi begitu jabatan tertinggi dipegang oleh A. Mukti Ali, praktis dominasi tersebut bergeser ke golongan modernis. Perebutan itu agaknya masih membias sampai sekarang.

blogspot.com/2010/11/muhammadiyah-dan-nu-dalam-kompetisi.html, diakses tanggal 20 Mei 2011. 
Kalau dipolakan hubungan antara Muhammadiyah dan NU dapat dibagi dalam tiga pola hubungan, yakni 1) konfrontatif teologis 1912-1985, hubungan konfrontatif ini sudah kelihatan sejak berdirinya NU yang merupakan reaksi atas ide-ide pembaharuan yang dilontarkan oleh K.H. Ahmad Dahlan melalui Muhammadiyah. Terjadi perbedaan antara kaum tradisionalis dengan modernis yang kemudian merembet kepada amaliyah ibadah. 2) Harmonis semu, 1986-2000, hubungan harmonis ini diawali dengan diberlakukannya UU Keormasan No. 8/1985, NU pada muktamar di Situbondo memutuskan kembali ke khittah 1926, dan Muhammadiyah pada konggres ke-41 memutuskan Pancasila sebagai Asas organisasi. Dari momentum inilah, dijadikan titik awal mempertemukan kedua organisasi itu. dan 3) konfrontatif politik, 2000-2001. Terjadinya konflik antara Amin Rais dan Gus Dur, yang mengakibatkan warga NU dan Muhammadiyah bentrok. ${ }^{33}$

\section{Analisis Teori Konflik Fungsional Lewis A. Coser terhadap Dinamika Relasi NU dan Muhammadiyah}

Berdasarkan uraian tentang pemikiran teori Konflik Fungsional Sosial Lewis A. Coser sebagaimana diungkapkan di depan, maka dapat dijelaskan beberapa hal terkait dengan dinamika relasi Muhammadiyah dan NU.

Coser dalam teori fungsional konflik nya memadukan dua teori, yaitu teori fungsional struktural versus teori konflik. Alasan Coser, kedua teori ini mengandung kebenaran tetapi tidak mampu menjelaskan kenyataan sosial secara menyeluruh, karena nyatanya masyarakat itu sesekali terlibat konflik, tetapi sesekali juga terlibat kesepakatan-kesepakatan. ${ }^{34} \mathrm{Hal}$ ini pula yang terjadi dalam hubungan antara Muhammadiyah dan NU di Indonesia. Konflik yang terjadi antara Muhammadiyah dan NU tidak terjadi terus menerus, dan tidak pula secara serempak terjadi di mana-mana, melainkan secara sporadis. Hubungan antara Muhammadiyah dan

33 Sudarno Shobron, Muhammadiyah dan Nabdlatul Ulama dalam Pentas Politik Nasional, (Surakarta : University Muhammadiyah Press, 2003), h. 172174.

${ }^{34}$ Depag RI, Konflik Etno, h. 4. 
NU tidak selalu harmonis, kadang bermesraan, kadang pula terjadi konflik. ${ }^{35}$ Kalau dipolakan hubungan antara Muhammadiyah dan NU dapat dibagi dalam tiga pola hubungan, yakni 1) konfrontatif teologis 1912-1985, 2) Harmonis semu, 1986-2000, 3) konfrontatif politik, 2000-2001. Setelah tahun 2001 sampai sekarang hubungan antara Muhammadiyah dan NU cenderung harmonis.

Selanjutnya Coser menyatakan konflik dalam masyarakat itu tidak selamanya disfungsional tetapi bisa fungsional. Salah satu fungsi konflik menurut Coser adalah, bahwa konflik merupakan suatu rangsangan atau stimulus utama untuk mencapai adanya perubahan sosial. Sejatinya perseteruan antara Muhammadiyah dan NU, baik yang terjadi pada aras paham keagamaan maupun aras kultural dan politik, dapat memberi penguatan bagi proses kemajemukan Islam di tanah air. Kekuatan Islam bukan hanya terletak pada adanya kesatuan (unity) pada wilayah fundamental keagamaan, tetapi juga, pada keragaman (diversity) kultural dalam wilayah historis dan sosiologis keagamaan umat Islam. Hal ini menjadi indikasi penting, Islam merupakan agama yang dapat berkembang pada semua kawasan yang punya keaneragaman kultural. Dalam konteks sejarah Islam di Indonesia, Kita tidak bisa membayangkan, kalau saja Muhammadiyah dan NU tidak muncul di Bumi Nusantara tercinta ini.

Konflik dalam pandangan Islam merupakan suatu hal yang biasa dan tidak destruktif. Sebab, konflik dalam pengertian perbedaan itu rahmat Tuhan yang dapat membawa kebaikan apabila dimaknai secara arif. Pemahaman seperti ini menumbuhkan kesadaran pluralisme dan pemikiran yang terbuka. Secara normatif bahwa perbedaan diakui dan diyakini sebagai suatu kewajaran yang bisa membawa rahmat. Argumen yang dikemukakan adalah sabda Nabi saw bahwa "Ikbtiläfu Ummati Rahmatun" (perbedaan pada umatku adalah rahmat). Dari uraian tersebut dapat dipahami bahwa konflik yang terjadi antara Muhammadiyah dan NU dapat mengakibatkan terjadinya perubahan sosial, yakni tertanamnya kesadaran pluralisme dan meningkatnya rasa toleransi dan terbuka terhadap orang lain.

35 Ibid. 
Dilihat dari jenisnya, maka konflik yang terjadi antara Muhammadiyah dan NU adalah konflik non realistik, dikarenakan cenderung bersifat ideologis. Konflik yang non realistis ini cenderung lebih sulit untuk menemukan solusinya atau sulit mencapai konsensus dan perdamaian. Penyelesaian konflik antara Muhammadiyah dan NU terus dilakukan. Namun, perbedaan dan konflik yang terjadi antara keduanya tidak mungkin sepenuhnya bisa dihilangkan secara radikal.

Akan tetapi Konflik antara Muhammadiyah dan NU ini, sebagaimana teori Coser dapat dikendalikan ketika semua kelompok dihadapkan pada tugas bersama yang merupakan tujuan bersama yang lebih tinggi (superordinate goals) yaitu mengedepankan syiar agama Islam dan ukhuwah Islam daripada mengedepankan paham keagamaannya, yang pencapaiannya tak mungkin tanpa partisipasi seluruh warga Muhammadiyah dan NU. Maka terjadilah tranformasi dari situasi konflik ke relasi antarkelompok yang harmonis antara Muhammadiyah dan NU.

Kini, siapapun tidak akan menyangkal bahwa dalam rentang satu dasawarsa terakhir ini, ada semacam akulturasi antara Muhammadiyah dan NU. Boleh dikata secara kultural tidak ada lagi sekat antara Muhammadiyah dan NU. Transformasi NUMuhammadiyah terjadi nyaris di semua lini kehidupan sosial. NU merambah hingga ke segmen-segmen masyarakat di perkotaan, sama seperti Muhammadiyah memasuki ranah-ranah di pedesaan.

Banyak anak NU belajar di lembaga-lembaga pendidikan Muhammadiyah, seperti halnya tidak sedikit generasi Muhammadiyah yang nyantri di pesantren-pesantren NU. Disparitas praktek ritual keagamaan yang selama ini menjadi ciri pembeda antara keduanya pun mulai luntur. Hal ini tampak pada fenomena tahlilan, tarawih, shalat Ied, dan sejenisnya. Walhasil, "agama NU" dan "agama Muhammadiyah" yang dulu pernah menjadi ironi dan menghantui ukhuwah islamiyah sedikit demi sedikit mulai beranjak dari balada Islam Indonesia. Kegiatan intelektual maupun sosial yang melibatkan kedua belah pihak inilah yang oleh Coser disebut sebagai katup penyelamat (savety value) yang dapat memperbaiki hubungan antara NU dan Muhammadiyah. 


\section{J. Penutup}

Hubungan antara Muhammadiyah dan NU mengalami pasang surut. Kadang bermesraan, kadang juga mengalami konflik. Namun Konflik yang terjadi antara Muhammadiyah dan NU tersebut sebagaimana teori konflik dari Coser tidak hanya bersifat disfungsional tetapi lebih banyak bersifat fungsional yakni persaingan dalam kebaikan (Fastabiqul Khoirot). Dengan adanya konflik, pemahaman kesadaran pluralisme dan pikiran terbuka tertanam kuat, sekaligus dapat memperkuat identitas ingroup antara warga Muhammadiyah dan NU. Penyelesaian konflik diantara keduanya dapat dilakukan melalui lembaga katup penyelamat (safety valve), misalnya kegiatan-kegiatan sosial dan intelektual yang melibatkan kedua belah pihak sebagaimana yang dilakukan oleh angkatan muda Muhammadiyah dan NU. []

\section{DAFTAR PUSTAKA}

Balitbang Agama dan Diklat Keagamaan, Konflik Sosial Bernuansa Agama di Indonesia, Jakarta: Depaq RI, 2003.

Coser, A Lewis, The Fungtions of Sosial Conflict, New York, USA, The Free Press, 1956

Dean G. Pruitt, Jeffrey Z. Rubin, Teori Konflik Sosial, terj. Helly P. Soetjipto dan Sri Mulyantini, Yogyakarta: Pustaka Pelajar, 2004.

Depag RI, Konflike Etno Religius Indonesia Kontemporer, Jakarta: Depag RI, 2003.

George Ritzer- Douglas J.Goodman, Teori Sosiologi Modern, Jakarta : Kencana, 2004.

Mulyadi, Konflik Sosial ditinjau dari Segi Struktur dan Fungsi, Makalah, Jurusan Antropologi, Fakultas Ilmu Budaya UGM, tanpa tahun, Yogyakarta..

Loekman Soetrisno, Konflik Sosial Studi Kasus Indonesia, tk: Tajidu Press, 200.

Maswadi Rauf, Konsensus Politik, Sebuah Penjajagan Teoritis, Jakarta: Direktorat Jenderal Pendidikan Tinggi, Depdiknas, 2000.

Poloma Margaret M, Sosiologi Kontemporer, Yasogama tim (terj.) Jakarta: PT. RajaGarfindo Persada, 2000. 
Ramlan Surbakti, Dasar-dasar Ilmu Politik, Surabaya: Airlangga University Press, 1984.

Sjamsudduha, Konflike \& Rekonsiliasi NU Mubammadiyah, Surabaya : PT. Bina Ilmu, 1999.

Sudarno Shobron, Muhammadiyah dan Nahdlatul Ulama dalam Pentas Politik Nasional, Surakarta: University Muhammadiyah Press, 2003.

Syafuan Rozi dkk, Kekerasan Komunal : Anatomi dan Resolusi Konflik di Indonesia, Yogyakarta: Pustaka Pelajar, 2006.

Syamsul Arifin, Menggagas Ukhuwah NU dan Mubammadiyah dalam

"Muhammadiyah-NU Mendayung Ukhuwah di Tengah Perbedaan", Malang: UMM Press, 2004.

Tim Penyusun Kamus Pusat Pembinaan dan Pengembangan Bahasa, Kamus Besar Bahasa Indonesia, Jakarta: Balai Pustaka, 1990.

Zainuddin Maliki, Narasi Agung: Tiga Teori Sosial Hegemonik, Surabaya: Lembaga Pengkajian Agama dan Masyarakat, 2003.

Zeitlin M Irving, Memahami Kembali Sosiologi, Sunyoto (peny.), Yogyakarta: Gadjah Mada University Press, 1998.

\section{Jurnal}

Argyo Demartoto,, Strukturalisme Konflik: Pemahaman Akan Konflik Pada Masyarakat Industri Menurut Lewis Coser Dan Ralf Dabrendorf, dalam Jurnal Dilema Sosiologi Issn : 0215 - 9635, Vol 24 No. 1 Tabun 2010.

\section{Internet}

Blasius Baene, Telaah Tentang Fungsionalitas Konflik Dalam Masyarakat Menurut Lewis A. Coser. Lihat http: http://sapereaudenias. blogspot.com/2008/08/telaah-tentang-fungsionalitaskonflik. html, diakses tanggal 20 Mei 2011

Pramono U Tanthowi, Muhammadiyah dan NU dalam Kompetisi Makna "Civil Society", Kompas, Jumat, 6 Juli 2001 http:/ / muhammadiyahstudies.blogspot.com/2010/11/muh ammadiyah-dan-nu-dalam-kompetisi.html, diakses tanggal 20 Mei 2011

http:/ / socialmasterpice.blogspot.com/2011/03/teori-konflik-coser -dahrendof.html 